\title{
PENGUATAN AKAD PEMBIAYAAN MUDHARABAH UNTUK MEREALISASIKAN MISI KEADILAN BERBISNIS PADA BAITUT TAMWIL TAMZIS WONOSOBO
}

\author{
Nur Fatoni ${ }^{1}$
}

\begin{abstract}
Baitut Tamwil TAMZIS is unique in terms of financing agreement courage to apply to the majority of its financing. BT TAMZIS understand the financing as "nggaduhke" of funds to members to be developed by way of trade. The risk of losses on these funds BT TAMZIS risk. This is evident when there is a fire Wonosobo market, Waterford and Magelang. To overcome $i t$, he has a security system when there is a loss of assets due to natural factors or human error accident outside as the fire. He made the assurance division that serves as an internal insurance. Guarantee fund paid for by the BT TAMZIS in a unique way as well. Members exempt from administrative costs at the time of withdrawal. Members receive financing without the discount. He was obliged to pay the funds ta'awun with specific tariff. The benefit fund is to liberate the remaining debt ta'awun members during a disaster.
\end{abstract}

Keywords : Financing, Mudharabah, Baitut Tamwil Wat Tamwil, TAMZIS,

\section{PENDAHULUAN}

Salah satu Baitul Mal Wat Tamwil (BMT) yang berani melakukan inovasi ke arah dominasi akad percampuran (khususnya mudharabah) adalah BMT Tamzis Wonosobo (sekarang telah berubah menjadi BT Tamzis) ${ }^{2}$. Ia memiliki badan hukum sejak tahun 1992, dan memiliki kantor pusat di Jl.K.Muntang Wonosbo. BT Tamzis didirikan di kretek Wonosobo 22 Juni 1992. Sejak tahun 1996 bidang mal dipisah dan diserahkan kepada bapelurzam Muhammadiyah, sehingga menjadi baitut tamwil. Pada tahun 2008 BT Tamzis telah memiliki 21 kantor yang tersebar di Jawa Tengah, DIY dan Jakarta.

BT Tamzis banyak melakukan perbaikan manajemen dan pelayanan nasabah dengan standart prinsip syari'ah. Diantaranya ia menghapuskan potongan pencairan dana pembiayaan, karena dinilai tidak memiliki dasar hukum dan dasar rationing. Di sisi lain ia konsisten dengan penerapan akad pembiayaan mudharabah. Hasilnya pada tahun 2008 sampai sekarang 90\% akad pembiayaan yang digunakan adalah mudharabah. $10 \%$ akad adalah murabahah. Akad mudharabah mendominasi karena mayoritas nasabah pembiayaannya membutuhkan dana untuk usaha bukan pengadaan barang. Akad pembiayaan murabahah hanya dilakukan khusus pada pembiayaan pembelian barang. ${ }^{3}$

\footnotetext{
${ }^{1}$ Dosen Fakultas Syari'ah IAIN Walisongo Semarang

E-mail: nur_fatoni@yahoo.com

${ }^{2}$ Profile Baitut Tamwil Tamzis

${ }^{3}$ Atabik Ali (manajer Operasional Tamzis), wawancara, 26 Februari 2010.
} 
Nasabah BT Tamzis mayoritas pedagang. Mereka melakukan pembiayaan (utang) untuk memperbesar usahanya. Konsekwensinya bisa sangat pahit, yaitu barang dagangan musnah karena bencana, atau bangkrut karena salah urus dalam menjalankan usaha. BT siap melaksanakan akibat hukum akad mudharabah, dimana untung dan rugi dibagi berdua antara BT dan nasabah sesuai dengan proporsi dan porsi masing-masing. ${ }^{4}$

Kejadian pahit yang pernah dialami BT Tamzis adalah terbakarnya pasar kliwon Temanggung 8 Desember 2008, Pasar Rejowinangun magelang 26 Juni 2008 dan pasar Grabag Secang 13 Desember 2009. Pada Kejadian itu sebagian besar nasabah tamzis di pasar-pasar tersebut mengalami kerugian besar, dagangan musnah, modal menipis, lapak tempat berdagang hilang. Dari kejadian tersebut berturut-turut BT tamzis membebaskan (menganggap lunas) utang nasabahnya di ketiga pasar tersebut sebesar 152 juta dari 8 pedagang di pasar Kliwon temanggung (Suara Merdeka, 2009), 107 juta dari 62 pedagang di pasar Rejowinangun Magelang (Suara Merdeka, 2010) dan 19 juta di pasar Grabag secang (Suara Merdeka, 2010). Menurut Drs.H.Saad selaku ketua pengurus koperasi dan Budi Santoso, SE selaku Direktur utama BT Tamzis, pelunasan utang tersebut adalah konsekwensi akad mudharabah antara BT tamzis dan nasabah. Ibaratnya tamzis punya kambing yang digaduhkan kepada nasabah, kambing tersebut telah mati, maka tamzis wajib menghapuskan nilai kambing tersebut dari catatan harta dan berarti nasabah bebas hutangnya. Logika yang Nampak sederhana dan nyata telah diamalkan masyarakat jawa pedesaaan benar-benar barang langka ditengah logika kapitalistik lembaga keuangan pada umumnya. ${ }^{5}$

Fenomena akad pembiayaan mudharabah di Baitut Tamwil Tamzis adalah sebuah keunikan, atas penerapan prinsip yang semestinya menjadi pilar sebuah Baitut Tamwil. Di saat lembaga lain masih "nyaman" dengan akad-akad pembiayaan murabahah yang dianggap memiliki resiko ekonomi kecil, Baitut Tamwil Tamzis melaksanakan akad pembiayaan mudharabah, dengan resiko ekonomi yang besar, namun memiliki nilai kepercayaan yang besar pula. Baitut tamwil Tamzis melakukan sesuatu yang menyalahi prilaku umum. BT Tamzis lebih membela idealitas dari pada hanyut dalam realitas semata. Salah satu hal yang menarik dari keunikan tersebut adalah meknisme back up kelembagaan untuk merealisasikan prinsip bagi hasil dalam akad pembiayaan di baitut Tamwil Tamzis.

\section{TELAAH TEORITIS}

Problematika Akad Pembiayaan Mudharabah dapat dilihat dari kontrak musdharabah yang dilakukan oleh lembaga keuangan syari'ah adalah kontrak investasi yang memiliki risiko tinggi. Ia diliputi oleh persoalan asimetric information, yaitu kondisi yang menunjukkan sebagian investor mempunyai yang lain tidak memiliki. Persolan asimetric information kaitannya dengan peluang inestasi pernah diteliti oleh Ross (1977:23-40). Harry dan Raviv (1990:321-349) meneliti model agency kaitannya dengan peluang investasi. Menurut penelitian tersebut, sebagaimana dikutip oleh Muhammad, menunjukkan adanya hubungan antara asimetrik information dan model agency dengan batas probabilitas (default probability) peluang investasi. Munculya asimetrik informasi dapat mempengaruhi besar kecilnya pendapatan investasi yang dijalankan. Asimetrik informasi bisa berbentuk moral hazard dan adverse selection. Adverse selection terjadi pada kontrak hutang ketika kualitas peminjam hanya mampu menyediakan atau mengembalikan tingkat pengembalian di luar batas ketentuan yang ditentukan, lebih kecil dari yang diminta. Moral hazard terjadi jika peminjam melakukan reaksi menyimpang atas kontrak yang disepakati.

\footnotetext{
${ }^{4}$ Budi Santoso,SE (Menejer Utama BT Tamzis) wawancara, 26 Februari 2010. ${ }^{5}$ Ibid
} 
Persoalan di atas diatasi dengan mekanisme pembiayaan bank syari'ah. Bank syari'ah menetapkan tahapan yang harus ditempuh oleh peminjam. Pinjaman yang diberikan dalam mudharabah adalah bersifat produktif, karena pengusaha akan menggunakannya untuk kepentingan pengembangan usaha seperti perdagangan dan industri. Mekanismenya memelukan syarat administratif dan ketentuan yang bersifat umum. Syarat administratif misalnya : (1) Formulir pendaftaran; (2) KTP dan kartu keluarga; (3) Proposal yang memuat gambaran umum usaha, rencana usaha, rincian dan rencana penggunaan dana, jumlah kebutuhan dana dan jangka waktu penggunaan dana; (4) Legalitas usaha meliputi akta pendirian, surat izin perusahaan dan tanda daftar perusahaan; (5) Laporan keuangan seperti neraca dan laporan untung rugi, data persediaan terakhir, data penjualan dan foto copy rekening bank; (6) Pedoman umum yang berkaitan dengan mekanisme pembiayaan mudharabah adalah: (7) Semua orang yang memenuhi syarat administrasi berhak mendapat pinjaman dari bank syar'ah, (8) Semua orang berhak menentukan besar kecilnya dana yang dibutuhkan. Bank hanya terikat ketentuan batas maksimal pemberian kredit (BMPK) adalah $20 \%$ dari modal pokok yang dimiliki bank. Misalnya jika bank memiliki modal dasar sebesar 800 juta mak BMPK yang diberikan kepada debitur adalah 160 juta untuk setiap debitur; (9) Modal sepenuhnya dari bank dan pengelolaan usaha sepenuhnya ditangani oleh pengelola tanpa campur tangan dari bank; (10) Pembiayaan yang masuk skala besar dibutuhkan jaminan yang besar nilainya $125 \%$ dari besarnya dana yang akan dipinjam; (11) Khusus bagi nasabah yang belum terakreditasi kejujurannya, jangka waktu ditetapkan dalam jangka waktu yang pendek; (12) Nasabah diwajubkan membayar angsuran setiap bulan sepanjang waktu yang disepakati. Besarnya cicilan tidak secara tetap ditentukan bank, tetapi cicilan tersebut harus selesai pada waktu yang telah disepakati. Bank Islam akan memberi potongan pada pelunasan sebelum waktunya; (13) Setiap penyaluran dana kepada nasabah, bank menindaklanjuti dengan pembinaan nasabah yang bersangkutan, sehingga pada waktunya nanti dapat pinjamannya kepada bank, (14) Pinjaman yang diberikan bukan merupakan uang tunai, tetapi merupakan dana untuk pengadaan barang/jasa yang diikat dengan perjanjian kredit. Dalam sistem mudharabah biaya dibebankan dalam bentuk bagi hasil yang diperhitungkan melalui prinsip kemanfaatan barang/modal yang dibiayai bank; (15) Perjanjian bagi hasil mulai diberlakukan secara efektif setelah proyek investasinya selesai sesuai dengan jangka waktu yang telah disepakati. Saat itu bank dan nasabah bersama-sama menghitung porsi bagian laba masing-masing. Bila terjadi kerugian maka bank akan menaggung kerugian tersebut; (16) Peminjam hendaknya merencanakan terlebih dahulu secara matang tentang usaha, tempat, lokasi, pasar dan jumlah biaya yang dibutuhkan. Bank mengadakan observasi terhadap semua rencana usaha yang akan dilakukan; (17) Peminjam hendaknya mempelajari administrasi praktis tentang pengelolaan usaha yang sedang ditekuninya sehingga unsur keterbukaan dan kejujuran dapat terbaca oleh bank ${ }^{6}$

\section{PEMBAHASAN}

Pembiayaan mudharabah di lembaga keuangan syari'ah memerlukan kehati-hatian karena memiliki tingkat resiko yang tinggi. Dana yang dipinjamkan kepada pegusaha adalah dana bank. Jika pengusaha rugi dalam melakukan bisnis dengan dana tersebut maka bank syari'ah menanggung kerugian tersebut. Kehati-hatian diarahkan untuk meniadakan kerugian tersebut, mengingat dana bank syari'ah adalah dana masyarakat yang dititipkan kepadanya. Menurut Adiwarman Karim ${ }^{7}$, mudharabah masuk dalam katagori natural uncertainty

\footnotetext{
${ }^{6}$ Abdulah Amir, Asuransi Syariah, Jakarta: PT. Elex Media Komputerindo, 2006, hal 88-95.

7 Adiwarman Karim, Bank Islam Analisa Fiqh dan Keuangan, Raja Grafindo Persada, Jakarta, 2004,
} hal 57-69. 
contracts. Analisis resiko pembiayaan berbasis natural uncertainty contracts adalah mengidentifikasi dan menganalisis dampak dari seluruh resiko nasabah sehingga keputusan pembiayaan yang diambil sudah memperhitungkan resiko yang ada dari pembiayaan mudharabah dan musyarakah. ${ }^{8}$

Penilaian resiko dalam pembiayaan mudharabah meliputi tiga hal, yaitu: (1) Business Risk (resiko bisnis yang dibiayai), yaitu resiko yang terjadi pada first way out, (2) Shrigking Risk (Resiko berkurangnya nilai pembiayaan mudharabah), yaitu resiko yang terjadi pada Second way out dan (3) Character risk (resiko karakter buruk mudharabah) yaitu resiko yang terjadi pada third way out.

Resiko bisnis yang dibiayai dipengaruhi oleh beberapa faktor, yaitu: (1) Industry Risk, yaitu resiko yang terjadi pada jenis usaha yang ditentukan oleh, pertama, karakteristik masing-masing jenis usaha yang bersangkutan. Kedua, kinerja jeuangan jenis usaha yang bersangkutan (industrial financial standart), (2) Faktor negatif lainnya yang mempengaruhi perusahaan nasabah, seperti kondisi group usaha, keadaan force majeure, permasalahan hukum, pemogokan, kewajiban off balancesheet(L/C import, bank garansi), market risk (forex risk, interest risk, security risk), riwayat pembayaran (tunggakan kewajiban) dan restukturisasi pembiayaan, (3) Resiko berkurangnya nilai pembiayaan mudharabah dipengaruhi oleh tiga faktor yaitu: (a) Unusual business risk, yaitu risiko bisnis yang biasa yang ditentukan oleh pertama, penurunan drastis tingkat penjualan bisnis yang dibiayai. Kedua, penurunan drastis harga jual barang/jasa dari bisnis yang dibiayayi. Ketiga, penurunan drastis harga barang/jasa dari bisnis yang dibiayai (b) Jenis bagi hasil yang dilakukan, apakah profit and loss sharing atau revenue sharing. Jika bagi hasilnya menggunakan profit and loss sharing, resiko muncul bila terjadi loss sharing yang harus ditanggung oleh bank. Jika menggunakan kenis revenue sharing, resiko yang muncul adalah bila nasabah tidak mampu menanggung biaya yang seharusnya ditanggung nasabah, sehingga nasabah tidak mampu melanjutkan usahanya dan (c) Disaster risk, yaitu force majeur yang dampaknya sangat besar terhadap bisnis nasabah yang dibiayai.

Adapun resiko karakter dipengaruhi oleh beberapa faktor, antara lain : 1 1) Kelalaian nasabah dalam menjalankan bisnis yang dibiayai bank, (2) Pelanggaran ketentuan yang telah disepakati sehingga nasabah dalam menjalankan bisnis yang dibiayai bank tidak lagi sesuai dengan kesepakatan dan (3) Pengelolaan internal perusahaan, seperti manajemen, organisasi, pemasaran, tehunis produksi dan keuangan, yang tidak dilakukan secara profesional sesuai standar pengelolaan yang disepakati antara bank dan nasabah.

Untuk mengantisipasi resiko karakter, bank menetapkan kovenan khusus pembiayaan musyarakah dan mudharabah. Bila terjadi kerugian yang disebabkan oleh resiko karakter, kerugian akan dibebankan kepada nasabah. Untuk menjamin nasabah mampu menanggung kerugian akibat resiko karakter tersebut, maka bank menetapkan adanya jaminan. Resiko eksekusi jaminan dimaksud tergantung pada: (1) Kesempurnaan pengikatan jaminan, (2) Nilai jula kembali jaminan, (3) Faktor negatif lainnya seperti tuntutan hukum pihak lain atas jaminan, lamanya taksasi ulang jaminan dan (4) Kredibilitas penjamin.

Resiko bisnis dan resiko penurunan nilai pembiayaan akan menentukan rating resiko nasabah (CRR). Jika kondisi resiko bisnis dan resiko penurunan nilai pembiayaan baik, maka CRR akan tinggi ratingnya, atau rendah resikonya. Skornya dapat dijelaskan pada tabel 1 berikut:

Tabel 1 Skor Kondisi Bisnis

\begin{tabular}{|l|l|l|}
\hline \multicolumn{1}{|c|}{ Rating } & \multicolumn{1}{|c|}{ Score } & \multicolumn{1}{c|}{ Tingkat resiko } \\
\hline $1=$ baik sekali & 5 & Very low risk \\
\hline $2=$ baik & 4 & Low risk \\
\hline
\end{tabular}

${ }^{8}$ Ibid 


\begin{tabular}{|l|l|l|}
\hline $3=$ cukup/sedang & 3 & Moderate risk \\
\hline $4=$ kurang & 2 & High risk \\
\hline $5=$ buruk sekali & 1 & Veri hiqh risk \\
\hline
\end{tabular}

Sumber: dikembangkan untuk penelitian

Kondisi internal perusahaan nasabah diukur dari hasil analisis aspek manajemen, teknis produksi dan keuangan perusahaan.kondisi keuangan perusahaan dibandingkan dengan kinerja keuangan rata-rata industri.

Rating industri diukur pada tingkat nasional dan ciri-ciri umum dapat dijelaskan pada tabel 2 sebagai berikut:

Tabel 2 Rating Industri Diukur Berdasarkan Kinerja

\begin{tabular}{|l|l|l|}
\hline Score & Industry risk rating & \multicolumn{1}{c|}{ Ciri-ciri umum } \\
\hline 5 & Very low risk & $\begin{array}{l}\text { Prospek permintaan sangat baik, struktur industri } \\
\text { sangat kuat, kinerja keuangan dan kinerja pinjaman di } \\
\text { atas rata-rata industri. }\end{array}$ \\
\hline 4 & Low risk & Di atas rata-rata kineja industri \\
\hline 3 & Moderate risk & $\begin{array}{l}\text { Rata-rata industri dengan prospek pertembuhan yang } \\
\text { memadai dan mempunyai kemampuan keuangan } \\
\text { yang cukup untuk membayar kembali pinjamannya. }\end{array}$ \\
\hline 2 & High risk & Di bawah rata-rata kinerja industri \\
\hline 1 & Very hiqh risk & $\begin{array}{l}\text { Industri berisiko untuk diberikan pinjaman dengan } \\
\text { prospek dan kemampuan keuangan yang meragukan. }\end{array}$ \\
\hline
\end{tabular}

Sumber: dikembangkan untuk penelitian

Eksekusi atas jaminan merupakan pembayaran kembali atas pembiayaan mudharabah dari hasil penjualan jaminan, apabila terjadi resiko karakter. ${ }^{9}$ Latar Belakang Penggunaan Akad Mudharabah di Baitut Tamwil Tamzis adalah akad mudharabah pada produk pembiayaan di Baitut Tamwil Tamzis adalah jawaban atas tantangan akad pembiayaan yang dihadapi BT Tamzis dan keinginan kuat untuk melaksanakan kegiatan bisnis yang sesuai syari'at. Pada masa awal mudharabah belum digunakan karena kondisi yang belum memungkinkan. Dalam kondisi seperti itu akad yang digunakan adalah qard dengan infaq. Akad mudharabah mulai dikaji dan dilaksanakan setelah ada perubahan kondisi, yaitu munculnya lembaga keuangan mikro yang menjadi kompetitor BT Tamzis, seperti BKK, BPR dan Kospin pada tahun 1998. Akad qard dengan Infaq tidak memadai untuk transaksi bisnis jasa keuangan syari'ah.

Pada saat BT Tamzis memulai langkah konsentrasi pada kegiatan tamwil, tantangan yang dihadapi dalam persaingan bisnis lembaga keuangan mikro di Wonosobo adalah para rentenir yang memungut bunga flat tinggi hingga $10 \%$ per bulan. Ketika yang dihadapi adalah rentenir, BT Tamzis mengambil kebijakan untuk menggunakan akad qard dan tambahan yang diminta dari para anggota yang menerima pembiayaan adalah infaq anggota untuk BT Tamzis. Hasilnya cukup bagus. Ada migrasi para anggota dari pinjam ke rentenir pindah pinjam ke tamzis. Infaq yang diberikan anggota cukup besar meskipun bersifat suka rela, tidak diberi patokan minimal infaq. BT Tamzis bisa eksis dengan situasi seperti di atas. Pada kurun waktu 1994 - 1998 infaq yang diberikan oleh nasabah masih berkisar 3 - 5\% per bulan dari qard yang diberikan BT Tamzis. Hal tersebut mampu menopang operasionalisasi Baitut tamwil. Anggota masih nyaman dengan akad tersebut, mengingat kompetitornya adalah rentenir.

\section{${ }^{9}$ Ibid}


Para kurun 1998an mulai muncul kompetitor baru yang lebih kompetitif, dengan memberi tawaran bunga rendah $2-4 \%$. Situasi tersebut mengganggu kemapanan akad qard dengan infaq di Baitut Tamwil Tamzis. Pilihan yang ada bagi tamzis adalah mengacu pada akad tamwi, yaitu murabahah, mudharabah dan musyarakah. Masing-masing memiliki karakter yang khas sesuai kebutuhan pembiayaan pada umumnya.

Murabahah lebih cocok untuk akad pertukaran khususnya jual beli. Model ini kurang cocok dengan anggota Baitut Tamwil tamzis yang sebagian besar adalah para pedagang mikro di pasar. Persoalan lain yang mungkin dihadapi adalah mundurnya jadwal pelunasan pembiayaan yang berpotensi merugikan lembaga karena tidak diperkenankan melakukan resceduling dengan menambah margin keuntungan. Akad murabahah tidak cocok untuk akad pembiayaan mayoritas anggota. Akad musyarakah memiliki karakteristik yang hampir sesuia. Ada percampuran modal anggota dan lembaga pada kegiatan bisnis anggota. Persoalan yang dihadapi adalah ketidakmampuan anggota menghitung aset bisnisnya, yang menyulitkan penghitungan porsi modal. Pilihan jatuh pada akad mudharabah. Mudharabah dinilai cocok untuk pembiayaan di baitut Tamwil Tamzis. Pertimbangan yang dilakukan adalah karakter anggota yang memiliki usaha telah berjalan sedangkan ia tidak mampu menghitung aset bisnisnya. Di sisi lain anggota bisa diperankan sebagai mudharib murni, ia adalah pihak yang dibiayai untuk pengembangan usaha, tanpa ada pembagian porsi modal. Pertimbangan filosofis yang paling dipakai oleh baitut tamwil tamzis adalah ekonomi syari'ah adalah bagi hasil. Bagi hasil yang bisa dilakukan oleh lembaga keuangan syari'ah adalah dengan memberi pembiayaan berupa penyediaan dana. Lembaga tidak mungkin melakukan kerjasama dalam bidang pekerjaan bisnis. Dengan begitu, akad yang paling tepat adalah kerjasama penyediaan dana oleh baitut tamwil yang dikuasakan pengembangannnya kepada anggota yang dipilih. Akad yang dianggap cocok adalah mudharabah. (Budi santoso, 2010.)

Proteksi Atas kerugian Pada pembiayaan mudharabah Di BT Tamzis. Sektor perdagangan yang dibiaya dengan akad mudharabah di BT Tamzis umumnya mikro. Akad yang digunakan adalah mudharabah muqayyadah, yaitu kerjasama yang dibatasi obyek bisnisnya. Pemikiran ini dimaksudkan untuk memperjelas obyek pembiayaan dan menghindari penyalahgunaan penggunaan pembiayaan. Kenyataan yang muncul banyak pedagang mikro yang menjual barang tambahan sebagai pelengkap barang pokok. Misalnya warung sate kambing. Ia bisa menjual bir bahkan minuman keras atas permintaan pembeli. Toko sembako biasa menjual rokok yang masuk katagori barang syubhat. Dalam rangka menjaga kekhalalan hasil usaha maka baitut tamwil Tamzis dalam melakukan akad pembiayaan dengan anggota menggunakan mudharabah terbatas -barang halal(muqayyadah).

Konsekwensi akad mudharabah adalah profit and loss sharing, siap untung siap rugi. Dana milik baitut tamwil tamzis bisa mengalam penyusutan bahkan hilang di tangan anggota sebagai mudharib. Risiko kerugian tersebut wajib diantisipasi oleh tamzis, mengingat dana yang disalurkan adalah milik anggota yang "ngaduhke" (kerjasama bagi hasil) kepada baitut tamwil tamzis. Perlindungan yang disiapkan mulai dari selektif memilih calon mudharib, mengikat kejujuran mudharib dengan jaminan fisik, menata tehnis pengembalian dana dan bagi hasil, penghapusan aktifa pasif dan membentuk dana ta'awun antar anggota penerima pembiayaan. Hal tersebut dalam rangka mengamankan dana nasabah dengan tetap konsisten pada akad mudharabah.

Seleksi calon mudharib dilakukan dengan menetapkan target keuntungan minimal berdagang di wilayah kerja masing-masing cabang baitut tamwail tamzis berdasarkan survei yang dilakukannya sendiri. misalnya di wonosobo, menurut survey keuntungan yang diambil oleh pedagang eceran antara 5-10\%. Oleh karena itu mudharib yang akan dibiayai adalah yang mampu meraih keuntungan minimal 5\% dari modal dalam satu transaksi. Tamzis akan menolak pedagang yang memiliki keuntungan kecil sebagai mudharib. Seleksi dilakukan 
melalui interaksi langsung (wawancara dan pengamatan) antara marketing Tamzis dengan calon mudharib. Syarat keuntungan minimal adalah tambahan dari syarat pokok yaitu 5C.

Pembiayaan muharabah dikemas bersama dengan tabungan harian. Mudharib memiliki keterbatasan waktu dan kesempatan untuk menyetor bagi hasil maupun pengembalian pokok ke kantor baitut tamwil tamzis. Mereka juga dikhawatirkan lalai jika dipersilahkan menyetor bagi hasil tiap akhir bulan, karena kelemahan dalam menejemen cash flow. Mudharib menabung harian melalui petugas tamzis yang datang ke tempat usaha mudharib. Hasil tabungan digunakan untuk membayar bagi hasil dan cicilan pokok dengan cara auto debet pada hari jatuh tempo. Ada keluwesan/ kelonggaran dalam mengembalikan pokok modal. Ia bisa dikembalikan kapanpun. Selama modal tamzis masih digunakan mudharib, maka tamzis masih berhak atas bagi hasil sesuai kesepakatan. Jika terjadi kelalaian mudharib yang menyebabkan hilangnya modal tamzis di tangan mudharib maka mdharib hanya diwajibkan mengembalikan pokok modal tersisa saja.

Pokok modal tamzis yang hilang/berkurang karena persoalan bencana maka tamzis menghapus modal tersebut dari aktifa produktifnya. Mudharib dibebaskan dari kewajiban mengembalikan pokok modal milik tamzis yang digunakan usaha. Ada dua cara untuk mengatasi kejadian bencana tersebut. Pertama dilakukan dengan dana cadangan resiko yang telah dikumpulkan/disisihkan dari pendapatan tamzis. Kedua, melalui dana mu'awanah. Mudharib membayar iuran mu'awanah pada saat menerima modal. Dana mu'awanah dikelola oleh tamzis. Mudharib hanya dikenai biaya administrasi riil seperti materai, dan dibebeskan dari biaya administrasi lainnya seperti profisi, komisi dan lainnya..

Adapun syarat Administrasinya adalah sebagai berikut: (1) Menjadi anggota Baituttamwil TAMZIS dengan membayar simpanan pokok sebesar Rp. 10.000,00 atau sudah mempunyai rekening/simpanan di Baituttamwil TAMZIS, (2) Mengisi formulir pembiayaan mudharabah, (3) Menyerahkan fotocopy identitas diri seperti KTP, SIM, Kartu Keluarga yang masih berlaku, (4) Pengajuan pembiayaan di atas Rp5 juta harus menyerahkan fotocopy agunan seperti BPKB, SHM, Los Pasar, dan Sertifikat IJABAH, (5) Untuk BPKB roda 2 dan 4 tahun 1995 ke atas dengan nomor polisi lokal, (6) Untuk SHM, jika bukan atas nama pribadi menggunakan surat kuasa (7) Bersedia di survei/cek fisik dan bersedia mengisi perjanjian pengikatan jaminan, (8) Obyek pembiayaan sektor usaha/perdagangan Lolos survei.

Kejujuran mudharib dipacu dengan pengikatan perjanjian pendanaan mudharabah dengan jaminan fisik di atas. Pada padasnya kerugian yang dialami mudharib adalah resiko shahibul mal selama terjadi tanpa kesengajaan dan atau kelalaian mudharib. Jika kerugian dana terjadi karena kelalaian mudharib dan atau kesengajaannya maka ia wajib mengganti dana shahibul mal. Kejujuran mudharib dalam menjaga amanah dana shahibul mal diikat dengan jaminan fisik berupa surat barang seperti srtifikat tanah, BPKB kendaraan bermotor roda 2 keatas. Bentuk surat barang lain seperti bukti kepemilikan los pasar dan sertifikat deposito. Pengikatan ini yang sering disalah artikan sebagai ketidak percayaan kepada mudharib. Karakter manusia modern nampaknya mengharuskan pengikatan tersebut untuk memacu kejujuran mudharib dalam melaksanakan bisnis dan berbagi hasil dengan Tamzis.

Untuk mengatasi kerugian lembaga karena faktor murni musibah (non manusia) maka baitut tamwil tamzis membuat mekanisme tertentu seperti asuransi sebagai berikut, anggota pembiayaan diwajibkan memberikan iuran guna menanggulangi resiko/kecelakaan yang mungkin terjadi di masa yang akan datang. Melalui cara ta'awun (tolong-menolong berbagai resiko) ini, sehingga Baitutttamwil TAMZIS dapat membebaskan sisa pembiayaan anggota yang mengalami musibah, seperti meninggal dunia, kebakaran pasar, maupun kecelakaan yang menyebabkan sakit/cacat tetap.

Baitut Tamwil Tamzis membuat Divisi Penjaminan, dan ia membuat Program Penjaminan Pembiayaan yang bertujuan untuk memberikan jaminan pelunasan terhadap 
pembiayaan mudharabah yang diberikan kepada anggota apabila anggota meninggal dunia atau mendapat musibah kebakaran tempat usaha maupun cacat tetap karena kecelakaan.

Penjaminan pembiayaan adalah suatu program proteksi/perlindungan pembiayaan kepada anggota yang meninggal dunia, tertimpa musibah kebakaran, sakit parah maupun cacat tetap karena kecelakaan dengan memberikan jaminan pelunasan pembiayaan sebesar sisa pembiayaan jika anggota meninggal dunia. ${ }^{10}$ Premi merupakan pembayaran sejumlah uang yang dilakukan pihak tertanggung kepada pihak penanggung untuk mengganti suatu kerugian, kerusakan, atau kehilangan keuntungan yang diharapkan akibat timbulnya perjanjian atau pemindahan risiko dari tertanggung kepada penanggung. ${ }^{11}$ Tabarru' adalah iuran kebajikan yang diniatkan oleh anggota untuk dana tolong-menolong apabila ada anggota lain yang terkena musibah. Dana tabarru'/premi penjaminan dibayarkan pada waktu akad pembiayaan ditandatangani dan besarnya dapat dijelaskan pada tabel 3 sebagai berikut: ${ }^{12}$

Tabel 3 Jangka Waktu Pembiayaan

\begin{tabular}{|l|l|l|}
\hline No. & \multicolumn{1}{|c|}{ Jangka Waktu } & \multicolumn{1}{c|}{ Dana Tabarru' Penjaminan } \\
\hline 1 & $<1$ bulan s/d 3 bulan & $0,75 \%$ dari plafond pembiayaan \\
\hline 2 & 4 bulan s/d 6 bulan & $1,0 \%$ dari plafond pembiayaan \\
\hline 3 & 7 bulan s/d 12 bulan & $1,25 \%$ dari plafond pembiayaan \\
\hline
\end{tabular}

Sumber: Tri Wuryanto, Bank Indonesia Senarang 2009.

Divisi Penjaminan akan menerbitkan tanda bukti setoran penjaminan bagi anggota yang ikut program penjaminan. Bukti setoran penjaminan digunakan untuk pengajuan klaim pembebasan pembiayaan. Jangka waktu penjaminan disesuaikan dengan lamanya masa pembiayaan yang diberikan oleh kantor cabang. Apabila jangka waktu pembiayaan sudah habis sedangkan pembiayaan belum lunas, maka anggota dapat memperpanjang program penjaminan dengan cara membayar lagi dana tabarru' penjaminan yang dihitung dari saldo akhir pembiayaan. ( Tri Wuryanto, 2010) ${ }^{13}$

Klaim merupakan suatu proses pengajuan oleh peserta untuk mendapatkan uang pertanggungan setelah tertanggung melaksanakan seluruh kewajibannya kepada penanggung, yaitu berupa penyelesaian pembayaran premi sesuai dengan kesepakatan sebelumnya. (Abdulah Amrin) ${ }^{14}$ Adapun syarat-syarat pengajuan klaim: (1) Surat pengajuan klaim, (2) Surat keterangan seperti surat kematian dari pemerintah daerah setempat, surat keterangan sakit dari rumah sakit, maupun surat keterangan terjadi kebakaran tempat usaha dari pemerintah daerah setempat, (3) Fotocopy KTP anggota, (4) Bukti setoran penjaminan, (5) Fotocopy akad pembiayaan mudharabah dan (6) Sejarah angsuran pembiayaan mudharabah.

Sedangkan prosedur pengajuan klaim pembiayaan mudharabah adalah sebagai berikut: (1) Klaim diajukan ke Divisi Penjaminan Baituttamwil TAMZIS pusat melalui Kadiv. Administrasi/Kadiv. Marketing di setiap kantor cabang (2) Pengajuan klaim harus menyertakan bukti setoran penjaminan dari kantor cabang dan copy akad pembiayaan serta rincian saldo pembiayaan (sejarah pembiayaan) (3) Untuk klaim cacat tetap/sakit parah disertai surat keterangan mengenai cacat tetap/sakit parah dari dokter maupun rumah sakit (asli atau fotocopy yang telah dilegalisir) dan (4) Untuk klaim kebakaran tempat usaha disertai surat keterangan kebakaran tempat usaha dari pemerintah daerah setempat, minimal dari kelurahan/desa (asli atau fotocopy yang telah dilegalisir). Untuk klaim meninggal dunia

${ }^{10}$ Tri Wuryanto, Program Penjaminan Pembiayaan, Bank Indonesia Semarang 2009, dikirim lewat email tanggal 8 April 2010.

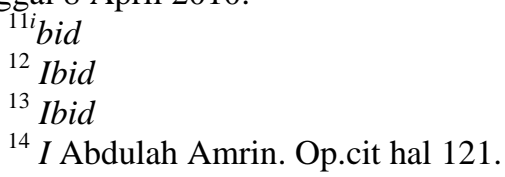


disertai surat keterangan meninggal dunia dari pemerintah daerah setempat, minimal dari kelurahan/desa (asli atau fotocopy yang telah dilegalisir).

Divisi Penjaminan di Baituttamwil TAMZIS telah merealisasikan prinsip dalam akad mudharabah, yaitu ikut menanggung kerugian pada usaha yang dibiayai dengan akad mudharabah. Kerugian yang ditanggung oleh Baituttamwil TAMZIS adalah kerugian yang merupakan resiko usaha, bukan karena kelalaian dan penyalahgunaan. Sampai sekarang, Divisi Penjaminan telah membebaskan sisa pembiayaan kepada anggota sebanyak 225 anggota dengan total dana ta'awun yang telah diberikan sebesar Rp. 445.318.228,- (rincian jenis musibah dan pembayarannya dapat dilihat di pada lampiran). (RAT. TAMZIS, 2010)

Pembayaran Klaim, Adapun prosedur pembayaran klaim penjaminan kepada anggota dalam rangka pembebasan pembiayaan mudharabah yang ikut serta dalam program penjaminan pembiayaan adalah sebagai berikut: (1) Divisi penjaminan akan memverifikasi data pengajuan klaim sebelum memberikan penggantian/pelunasan pembiayaan dengan jangka waktu maksimal 1 bulan (2) Pembayaran klaim akan dilakukan Divisi Penjaminan setelah verifikasi data selesai dan (3) Pembayaran klaim memperhitungkan kondisi dana cadangan klaim yang ada dengan batasan maksimal sebesar dana cadangan klaim yang ada. Contoh Kasus : Bapak A mengambil pembiayaan mudharabah di kantor cabang Baituttamwil TAMZIS Wonosobo. Plafond pembiayaan yang diberikan sebesar Rp. 4.000.000,- dengan masa pembiayaan selama 4 bulan. Angsuran dilakukan setiap hari dengan asumsi Rp. 1.000.000,-/bulan. Dimana kantor cabang Wonosobo mengikuti program penjaminan pembiayaan.

Dalam rangka untuk mengembangkan pelayanan kepada anggota, Baituttamwil TAMZIS membuka kantor cabang Baituttamwil TAMZIS yang tersebar di pulau jawa sebanyak 26 kantor cabang, 1 kantor pusat di Wonosobo, dan 1 kantor pusat non operasional di Jakarta. Dimana semua kantor cabang diikutsertakan dalam program penjaminan. Adapun pengelolaan program penjaminan oleh Divisi Penjaminan adalah sebagai berikut: (1) Pengelolaan program penjaminan dilakukan oleh Divisi Penjaminan dengan mengikutsertakan seluruh kantor cabang Baituttamwil TAMZIS (2) Kantor cabang menerima setoran dana tabarru'/premi penjaminan dari anggota yang menerima pembiayaan dan memberikan bukti setoran penjaminan pembiayaan kepada anggota (3) Divisi Penjaminan membuka rekening simpanan di setiap kantor cabang untuk menampung setoran dana tabarru'/premi penjaminan (4) Kantor cabang akan membukukan setoran dana tabarru'premi penjaminan dari setiap anggota pembiayaan ke dalam rekening Divisi Penjaminan (5) Pembagian penerimaan dana tabarru'/premi penjaminan 50\% sebagai dana ta'awun dan 50\% sebagai pendapatan premi, (6) Divisi Penjaminan memberikan insentif pengelolaan ke kantor cabang sebesar $50 \%$ dari porsi pendapatan premi di kantor cabang tersebut, (7) Kantor cabang memberikan laporan via SMS ke Divisi Penjaminan setiap akhir bulan tentang akumulasi dana tabarru'/premi penjaminan yang diterima setiap bulan (8) Divisi Penjaminan berhak untuk memeriksa ke seluruh kantor cabang mengenai data-data penjaminan (9) Divisi Penjaminan membuat laporan perkembangan dan keuangan setiap bulan kepada Manajemen Baituttamwil TAMZIS. (Tri Wuryanto) $^{15}$

Adapun perhitungan dana tabarru' yang dihimpun dari anggota pembiayaan mudharabah adalah sebagai berikut: Dana tabarru'premi penjaminan: Pembiayaan mudharabah tahun 2009 adalah sebesar Rp. 73.011.658.049,-. Dimisalkan dengan jangka waktu 4 bulan s/d 6 bulan dengan premi $1 \%$ dari plafond pembiayaan: $1 \% \mathrm{X}$ Rp. 73.011.658.049 = Rp. 730.116.580,- (1) Dana ta'awun untuk realisasi pembebasan pembiayaan mudharabah sebesar 50\% dari dana tabarru', yaitu: 50\% X Rp. $730.116 .580=$ Rp.365.058.290,- dan (2) Pendapatan premi sebesar 50\% dari dana tabarru', yaitu: $50 \% \quad \mathrm{X}$

\footnotetext{
${ }^{15}$ Ibid
} 
Rp. $730.116 .580=$ Rp. 365.058.290,-. Setiap kantor cabang memperoleh pendapatan dari premi penjaminan. Pendapatan tersebut sebesar 50\% dari pendapatan premi yang diperoleh masing-masing kantor cabang Baituttamwil TAMZIS.

Realisasi pembebasan pembiayaan yang dilakukan Baituttamwil TAMZIS kepada para anggotanya yang menjadi korban kebakaran tempat usaha, kecelakaan, dan meninggal dunia merupakan bagian dari pelaksanaan ekonomi syari'ah dengan pola mudharabah. TAMZIS menerapkan ekonomi syari'ah sebagai sistem yang mengedepankan aspek keadilan. Oleh karena itu sudah menjadi keniscayaan untuk membebaskan sisa pembiayaan dalam kerjasama pola mudharabah ketika anggota pembiayaan mudharabah di Baituttamwil TAMZIS mengalami kerugian akibat peristiwa yang bersifat Post Majeur, seperti kebakaran di pasar Temanggung, di pasar Rejowinangun Magelang dan pasar Wage di Purwokerto.

Sementara itu pembebasan pembiayaan tidak mengurangi performa Baituttamwil TAMZIS sebagai lembaga keuangan karena dana yang dipergunakan untuk memberikan pembebasan tersebut berasal dari dana ta'awun yang telah dikumpulkan selama ini dari seluruh anggota pembiayaan di Baituttamwil TAMZIS secara nasional. Akan tetapi pembebasan sisa pembiayaan tersebut harus berdasarkan penilaian terlebih dulu terhadap kerugian yang dialami oleh anggota pembiayaan.

Adapun realisasi pembebasan sisa pembiayaan yang dilakukan Baituttamwil TAMZIS diantaranya, pada tanggal 16 Januari 2010, Baituttamwil TAMZIS memberikan pembebasan sisa pembiayaan kepada anggota pembiayaan akibat kebakaran pasar Grabag Magelang. Pembebasan sisa pembiayaan tersebut berlangsung di Aula Kecamatan Grabag Magelang yang diberikan langsung oleh Manager Utama Baituttamwil TAMZIS Budi Santoso, didampingi Wakil Manager Tri Supriyo Wijiyanto dan Manager Divisi Penjaminan Baituttamwil TAMZIS Tri Wuryanto. Sejumlah 18 anggota pembiayaan korban kebakaran mendapatkan pembebasan sisa pembiayaan dengan jumlah total sebesar Rp. 19.000.000,-

Setelah di Magelang, pada hari Jum'at 12 Februari 2010 dilaksanakan pula pembebasan sisa pembiayaan Baituttamwil TAMZIS kepada anggota pembiayaan korban kebakaran pasar Ujungberung, Bandung, Jawa Barat. Pembebasan sisa pembiayaan tersebut berlangsung di Aula Kecamatan Ujungberung yang diberikan langsung oleh Ketua Pengurus Baituttamwil TAMZIS H. Saat Suharto kepada 21 anggota pembiayaan dengan total pembebasan sebesar Rp. 30.758.000,-. H. Saat Suharto didampingi Wakil Manager Tri Supriyo Wijiyanto, Manager Divisi Penjaminan Tri Wuryanto, serta Manager Marketing Area Jakarta Ridwan Edi Nugroho.

\section{PENUTUP}

Akad mudharabah pada pembiayaan di baitut Tamwil Tamzis dilatar belakangi oleh kebutuhan akad yang sesuai syari'ah pada model pembiayaan yang dilakukan oleh tamzis. Para anggota adalah pedagang pasar yang mikro, dengan skim pembiayaan yang relatif kecil. Kebutuhan akad ini didasarkan atas motifasi ingin kembali ke akad Syari'ah. Akad mudharabah dilakukan dalam konteks pemaknaan "nggaduh". Dana yang dipinjamkan kepada nasabah adalah dana milik tamzis yang diharapkan keuntungannya. Resiko kerugiaan dilindungi oleh mekanisme yang laksanakan divisi penjaminan. Back up kelembagaan sangat memudahkan pelaksanaan akad mudharabah. 


\section{DAFTAR PUSTAKA}

Abdulah Amir, (2006), Asuransi Syariah, Jakarta: PT. Elex Media Komputerindo.

Adiwarman Karim, (2004), Bank Islam Analisa Fiqh dan Keuangan, Jakarta, Raja Grafindo Persada.

Majalah Tamaddun Edisi XXI/th.V/Februari 2010

Profile Baitut Tamwil Tamzis, 2010, Wonosobo.

Tri Wuryanto, 2009, Program Penjaminan Pembiayaan, Bank Indonesia Semarang, diakses pada 8 April 2010. 
